\title{
Analysis of Overburden Structure and Pressure-Relief Effect of Hard Roof Blasting and Cutting
}

\author{
Hao Liu, ${ }^{1}$ Jin Dai, ${ }^{2}$ Jinquan Jiang, ${ }^{1,2}$ Pu Wang $\mathbb{D}^{1,2}$ and Jiqiang Yang ${ }^{3}$ \\ ${ }^{1}$ State Key Laboratory of Mining Disaster Prevention and Control Co-founded by Shandong Province and \\ the Ministry of Science and Technology, Shandong University of Science and Technology, Qingdao 266590, China \\ ${ }^{2}$ Department of Resources and Civil Engineering, Shandong University of Science and Technology, Tai'an 271019, China \\ ${ }^{3}$ China Coal Tianjin Design Engineering Co., Ltd., Tianjin 300120, China \\ Correspondence should be addressed to Pu Wang; 15854848872@163.com
}

Received 2 March 2019; Revised 8 August 2019; Accepted 26 August 2019; Published 16 September 2019

Academic Editor: Zahid Hossain

Copyright (c) 2019 Hao Liu et al. This is an open access article distributed under the Creative Commons Attribution License, which permits unrestricted use, distribution, and reproduction in any medium, provided the original work is properly cited.

\begin{abstract}
When studying the pressure-relief effect of hard roof blasting and cutting, the roof-cutting position and angle obviously affect the stability of the rock surrounding the gob-side entry (GSE). In this paper, control of the large deformation of rock surrounding the GSE is evaluated on the basis of the overlying structure and pressure-relief principle caused by roof cutting. Moreover, a mechanics model of a three-hinged arch structure (THAS) and a universal distinct element code (UDEC) numerical model with regard to the overlying rock movement were established to study the relationship among the rotation angle of key blocks in the THAS, the width of the roadway and the wall force beside it, and the optimal cutting position and cutting angle to reveal the pressure-relief effect of roof blasting and cutting and its influence on the support stability of the roadway. The results show that the overlying rock can form a stable THAS after roof blasting and cutting and that the wall stress and the coal-wall displacement are small, which indicates that roof blasting and cutting results in obvious pressure relief. The wall force increases with an increase in the rotation angle of the key block and decreases with an increase in the roadway width. Moreover, the optimal roof-cutting position $(5 \mathrm{~m})$ and angle $\left(15^{\circ}\right)$ are obtained with the specific mining conditions. Finally, on-site monitoring of the anchor-cable force and support force in panel 5312 of the Jining no. 3 coal mine is used to verify the pressure-relief effect after roof blasting and cutting. The study results can provide a theoretical basis for reasonable technical means and optimization of supporting parameters in field observation and have important application value for roof cutting and pressure relief for GSE retaining (GSER) technology.
\end{abstract}

\section{Introduction}

Based on green, scientific, and efficient mining of coal resources, gob-side entry retaining (GSER) technology has been widely applied to underground coal mines. This technology essentially realizes continuous mining without a coal pillar, reduces the roadway excavation rate, eases the difference between mining and excavation, and optimizes the mining layout. However, this technology is restricted by several shortcomings in its development and application such as the diversity of roof position, difficulty in controlling large deformation of the surrounding rock, and mismatch between the characteristics of the wall support and the surrounding rock [1-4].
For that reason, in-depth studies on the key technologies of GSER such as the surrounding rock activity, wall support, and roadway support have been conducted [5-9]. Because GSER is applied along the edge of the goaf after mining of the working face, the stability of the surrounding rock might depend on the mechanical response of roof failure. The sliding-rotating (S-R) stability based on the Voussoir beam theory was put forward by Qian et al. $[10,11]$ regarding the key block, and the mechanics criterion of slipping or rotary instability for the key block was obtained. The lateral roof of the roadway at the goaf side might break at the elastic-plastic junction; thus, the fracture position of key strata was obtained according to the limit equilibrium theory [12-16]. Guo and Zhao [17] determined that the fracture 
location of the lower roof of the retaining roadway plays a guiding role for the entire roof of the gob-side entry (GSE).

When a hard, thick, main roof occurs over a coal seam where no immediate roof is present or the immediate roof is thinner, the wall beside the roadway may have difficulty in supporting the hard roof. Therefore, it is necessary to presplit the hard roof and to change the main roof structure, thus resulting in effective pressure alleviation of the GSE [18-22]. At present, commonly used methods for roof presplitting are blasting presplitting and hydraulic fracturing [23, 24], which can effectively cut off the overhanging roof above the retaining roadway and result in roof caving. However, when using hydraulic fracturing for a hard roof, the mechanical properties of the roof decrease through the interaction of rock and water $[25,26]$. Therefore, blasting presplitting is generally used for a hard roof. The traditional use of roof blasting and pressure relief is to advance the presplitting blasting on the roof, which can speed up the movement and reduce the length of the cantilever block, thus reducing the pressure and the deformation of the surrounding rock. In addition, a vertical blasting model of bedrock was established through optimizing the charge structure of borehole, and then the influence of blasting-hole diameter on the blasting effect is determined by using a numerical simulation and field test [27, 28]. $\mathrm{Cu}-$ mulative blasting technology with directional presplitting under composite-roof condition was adopted to effectively control the damage of roof and maintain the integrity of the collapsed roof [29]. A dynamic load numerical model which regards artificial blasting as the earthquake source was established in order to analyze the failure and deformation of surrounding rocks [30]. However, these previous studies do not consider the importance of the structure formed by roof collapse and movement.

Hence, it is particularly important to select the best cutting position (hole position) and angle (hole angle) when presplit blasting the roof to achieve better pressure-relief effects. In this paper, to control the large deformation of rock surrounding the GSE, the overlying structure and pressurerelief principle caused by roof cutting was first analyzed. A THAS mechanics model and a UDEC numerical model with regard to the overlying rock movement were established to study the relationship among the rotation angle of key blocks in THAS, the width of the roadway and the wall force beside it, and the optimal cutting position and cutting angle to reveal the pressure-relief effect of roof blasting and cutting and its influence on the support stability of the roadway. The study results can provide a theoretical basis for reasonable technical means and optimized supporting parameters in field observation. Moreover, they have important application value for roof cutting and pressure relief using GSER technology.

\section{Analysis of Pressure Relief Caused by Roof Blasting and Cutting}

2.1. Overburden Structure and Pressure-Relief Principle Caused by Roof Cutting. When a hard, thick, main roof occurs directly above a coal seam, it is easily suspended at a large scale owing to its high stiffness and strength, which results in highly concentrated stress in the surrounding rock of the roadway [31-34]. Hence, if the roof is presplit by blasting in a certain range outside the GSE, the length of the cantilever block can be reduced, and the caved rock block can be squeezed and bitten with the noncaved block to form a stable articulated structure, thus reducing the pressure and alleviating the deformation of the rock surrounding the GSE.

The overburden structure after roof blasting was applied is shown in Figure 1. As shown in Figure 1(a), the $B_{2}$ block is rotated, and its right side touches the floor first. The block still intersects with and presses against the $\mathrm{B}_{1}$ block to form a beam structure owing to the effect horizontal force and the frictional resistance of joint-cutting. This results in load exertion on the roadway and shows a poor pressure-relief effect. In Figure $1(\mathrm{~b})$, the key $\mathrm{B}_{2}$ block is completely cut down after roof cutting and has lost mechanical transmission with the $\mathrm{B}_{1}$ block, which has a short or even no cantilever. However, the position of roof cutting should not be too close to the roadway in the field mainly because the blasting vibration caused by roof cutting will cause large deformation of the rock surrounding the roadway. In Figure $1(\mathrm{c})$, the key $\mathrm{B}_{2}$ block has subsided after roof cutting, and the $B_{1}$ block is suspended for a certain length. Then, the $B_{1}$ block was rotated and squeezed with the $B_{2}$ block with face mining. This resulted in the formation of a three-hinged arch overlying structure transferred from the cantilever beam structure and thus reduced the pressure of the wall and surrounding rock.

2.2. Determining Parameters of Roof Cutting. According to the aforementioned analysis, the overlying structure after roof cutting is very important for the stability of the surrounding rock in GSER technology. The basic parameters determining the overlying structure are the position and the angle of roof cutting.

2.2.1. Theoretical Analysis of Roof-Cutting Angle. According to the Voussoir beam theory [10], in order to ensure the slipping of block $\mathrm{B}_{2}$, the shear force must be greater than the friction force between the two blocks as

$$
\frac{R}{T} \geq \tan (\varphi-\beta)
$$

where $R$ is the shear force with the block failure, $\mathrm{N} ; T$ is horizontal force, $\mathrm{N}$; and $\beta$ is the angle of the roof cutting.

The possibility of slipping instability of the structure increases with an increase in the cutting angle. However, the cutting angle should not be too large, which may cause the drill-hole depth to increase, thus increasing the difficulty of construction.

2.2.2. Theoretical Analysis of Roof-Cutting Position. If the $\mathrm{B}_{2}$ block slips and loses stability after roof cutting, the relationship among the rotation angle, cutting angle, and cutting position is described by drawing a method according to the geometric relationship of the blocks, as shown in Figure 2. The $\mathrm{B}_{1}$ block rotated more easily and sank with a decrease in the cutting angle; then, it made contact with the $\mathrm{B}_{2}$ block to form a THAS. 


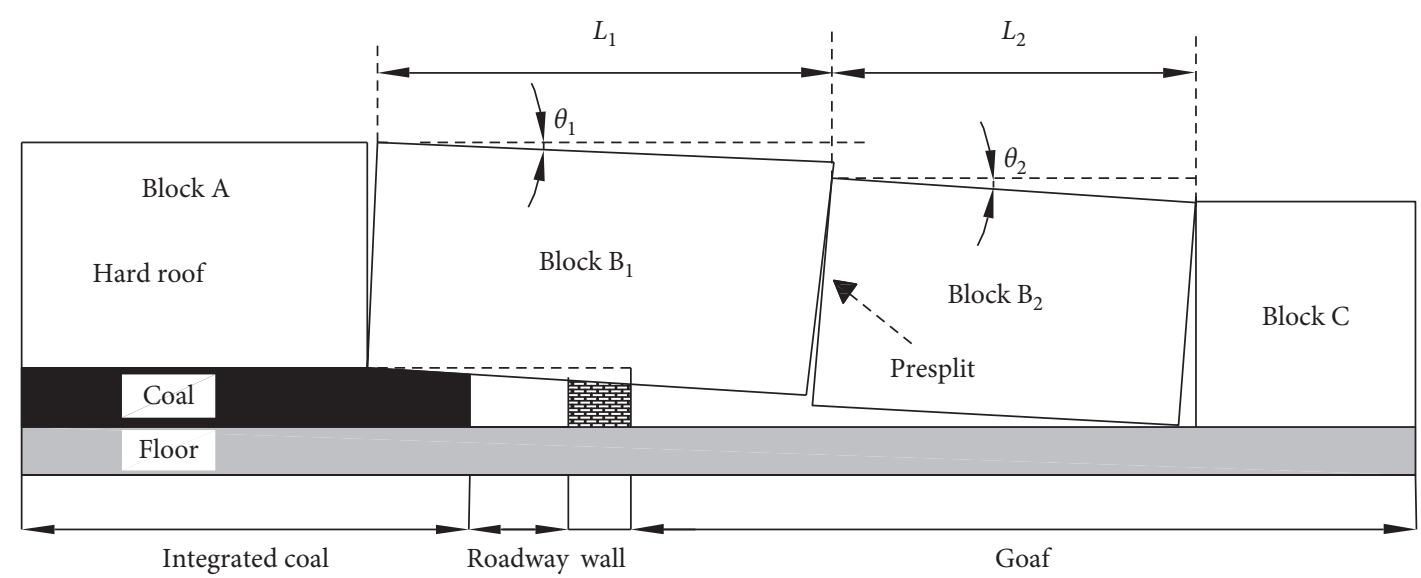

(a)

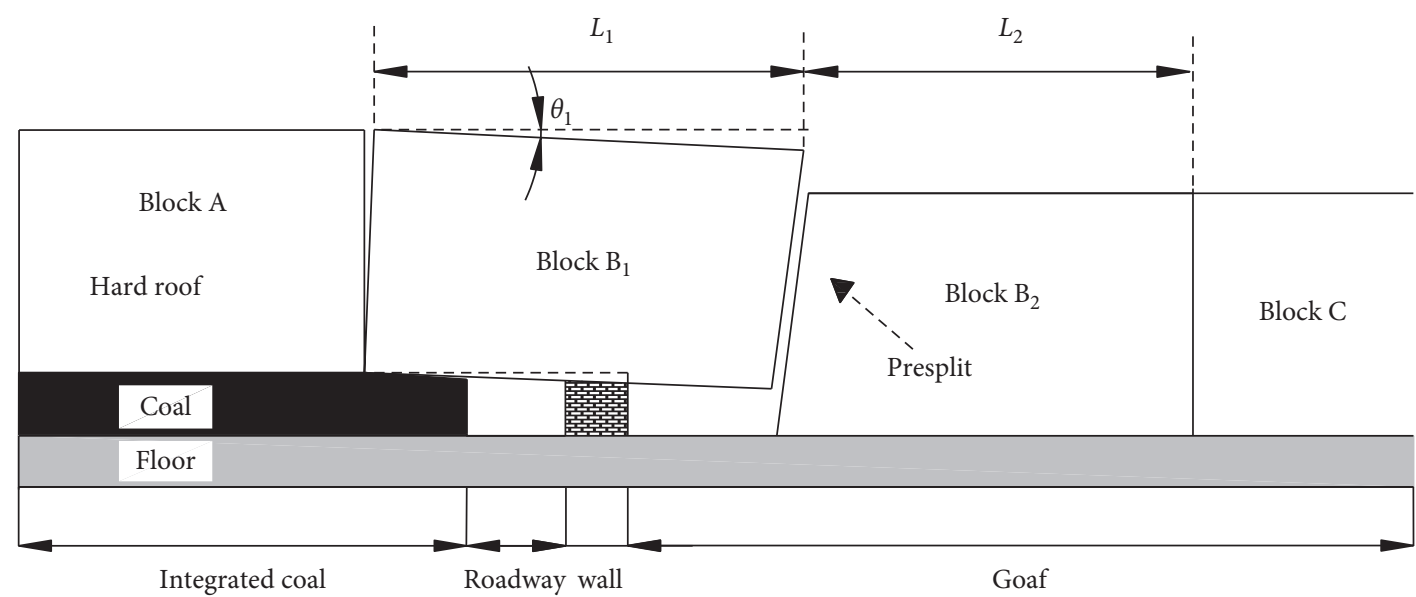

(b)

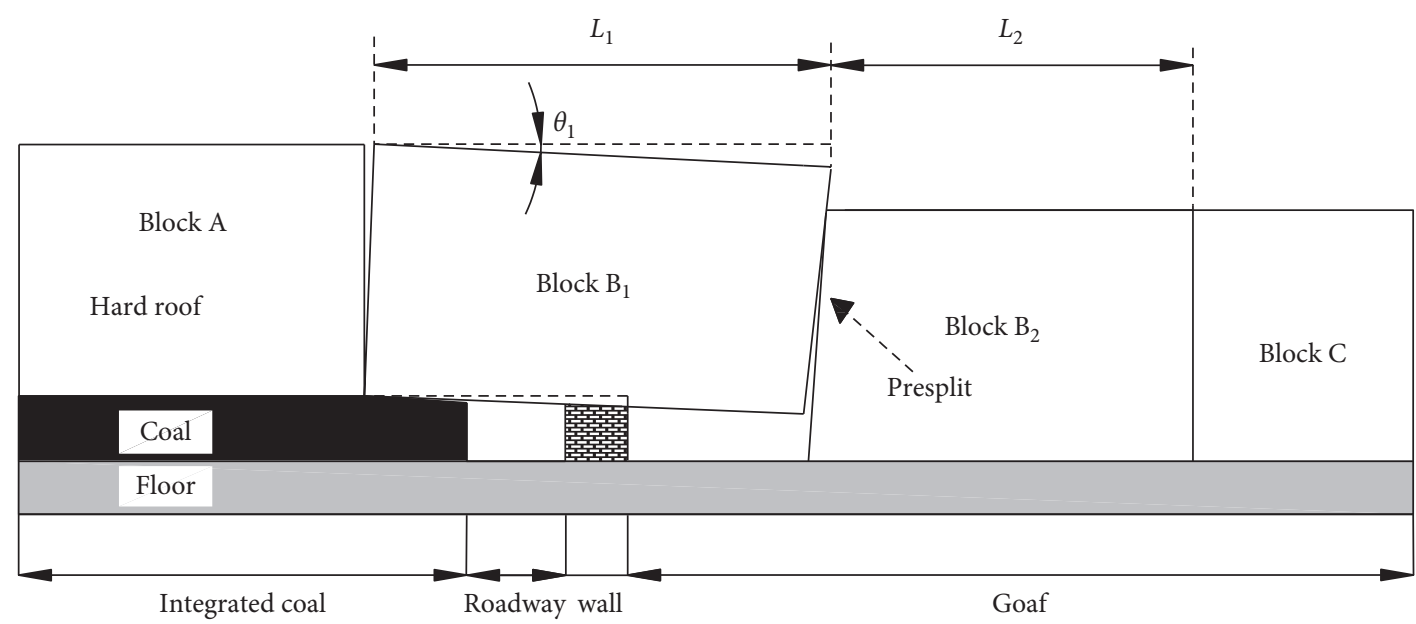

(c)

FIgURE 1: Roof structure of GSE affected by roof cutting.

According to the above analysis, the THAS easily forms with a large cutting position or small cutting angle. However, a longer cantilever relates to high support stress of the roadway with a larger cutting position; thus, the $B_{2}$ block may slip more easily with a large cutting angle according to equation (1). Hence, it is necessary to choose an appropriate cutting angle and cutting position to form a THAS.

\section{Mechanical and Parameter Analysis of Overburden Structure Caused by Roof Cutting}

3.1. Mechanical Model and Numerical Example Analysis of Overburden Structure. In order to better understand the pressure-relief effect of THAS after roof cutting, the 


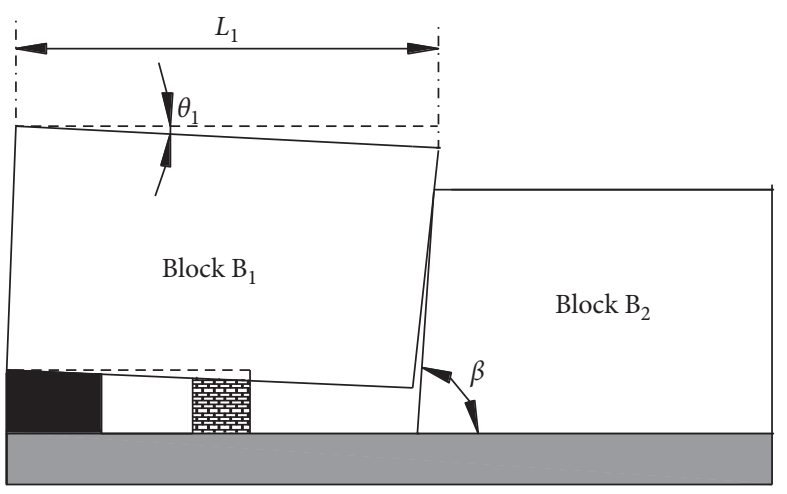

(a)

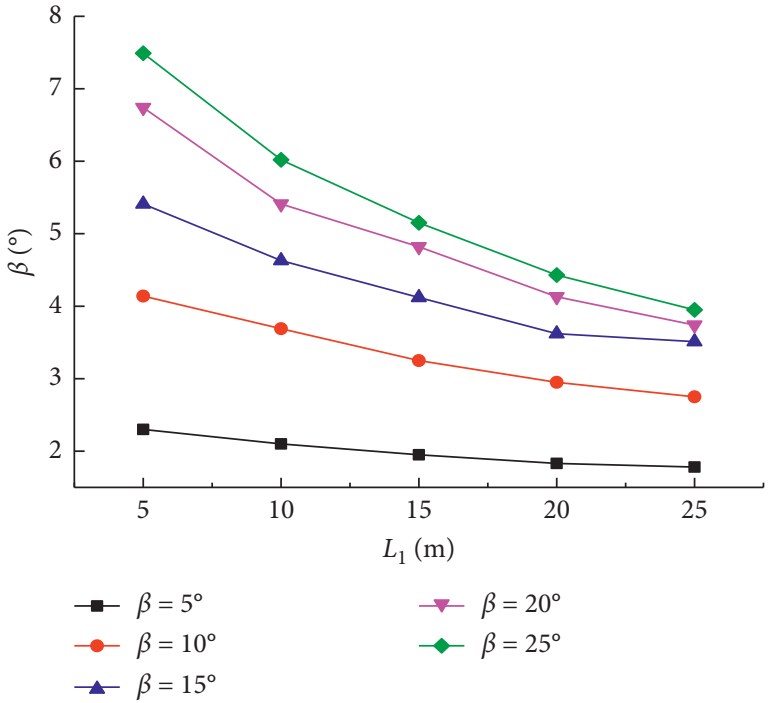

(b)

FIGURE 2: Relationship among rotation angle, cutting angle, and cutting position. (a) Geometric relationship between blocks; (b) relationship between the rotation angle and cutting position.

short-arm beam structure was set as the matched group, the mechanical model of the key block was established, and the engineering example was analyzed.

Figure 3 shows the force condition of the key strata with the THAS formation. According to the S-R stability theory, equation (2) is obtained:

$$
\begin{aligned}
\sum M_{A}= & 0 \frac{e}{2} T+\frac{1}{2} q L_{1}^{2}-f L_{1} \\
& -P\left(a+b+\frac{c}{2}\right)-T(h-m)=0,
\end{aligned}
$$

where $T$ is the horizontal force and $T=q L_{1}^{2} / 2(h-$ $\left.L_{1} \sin \theta_{1}\right) ; f$ is the friction force between two adjacent blocks and $f=T \tan \varphi ; \tan \varphi$ is the friction coefficient; $P$ is the wall force, $\mathrm{N} ; q$ is the uniform load, $q=\gamma_{i} h_{i} ; \gamma_{i}$ and $h_{i}$ are the density and the height of the main roof and its overlying strata, respectively; and $e=1 / 2\left(h-L_{1} \sin \theta_{1}\right)$. Hence, equation (3) can be expressed by the above parameters:

$$
P=\frac{\left((q \tan \varphi) /\left(2\left(h-L_{1} \sin \theta_{1}\right)\right)\right) L_{1}^{3}-\left(\left(q\left(m-3 L_{1} \sin \theta_{1}\right)\right) /\left(8\left(h-L_{1} \sin \theta_{1}\right)\right)\right) L_{1}^{2}}{a+b+(c / 2)} .
$$

Figure 4 shows the force condition of the key strata with the cantilever beam structure. Thus, the following equations are obtained:

$$
\begin{aligned}
\sum M_{A} & =0 \frac{1}{2} q L_{1}^{2}-P\left(a+b+\frac{c}{2}\right)=0, \\
P & =\frac{q L_{1}^{2}}{2 a+2 b+c} .
\end{aligned}
$$

Hence, when the cantilever beam structure and THAS are formed, the wall force increases with an increase in $L_{1}$.

Among them, the wall force $P$ of the cantilever beam structure is minimal with $L_{1}=a+b+c$; when $a$ THAS forms, $L_{1}$ needs to satisfy the geometric relations in Figure 2 .

In order to study the problem intuitively, panel 5312 of the Jining No. 3 coal mine was used as the mining background. The depth of panel 5312 is $581 \mathrm{~m}$, the mining height is $3 \mathrm{~m}$, the coal seam dip is $3-6^{\circ}$, and the length and the strike length are $150 \mathrm{~m}$ and $626 \mathrm{~m}$, respectively. The excavation size of the GSE is $4.5 \mathrm{~m} \times 3 \mathrm{~m}$, and the width of the wall is $2.7 \mathrm{~m}$. Moreover, the roof is composed mainly of interbedded sandstone and mudstone. The physical and mechanical parameters of the coal and the roof are listed in Table 1.

The length $L$ of the B block can be obtained as [8]

$$
L=\frac{2 u}{17}\left(\sqrt{\left(10 \frac{z}{u}\right)^{2}+102}-10 \frac{z}{u}\right)
$$

where $u$ is the length of working face, $\mathrm{m}$; $z$ is the periodic weighting distance obtained by field observation or calculated by $z=2 h \sqrt{\left(R_{T} / q\right)}$; and $R_{T}$ is the tensile strength, MPa.

Considering the effect of the elastic foundation, the horizontal distance between the break line of the roof and the roadway can be obtained as [1] 


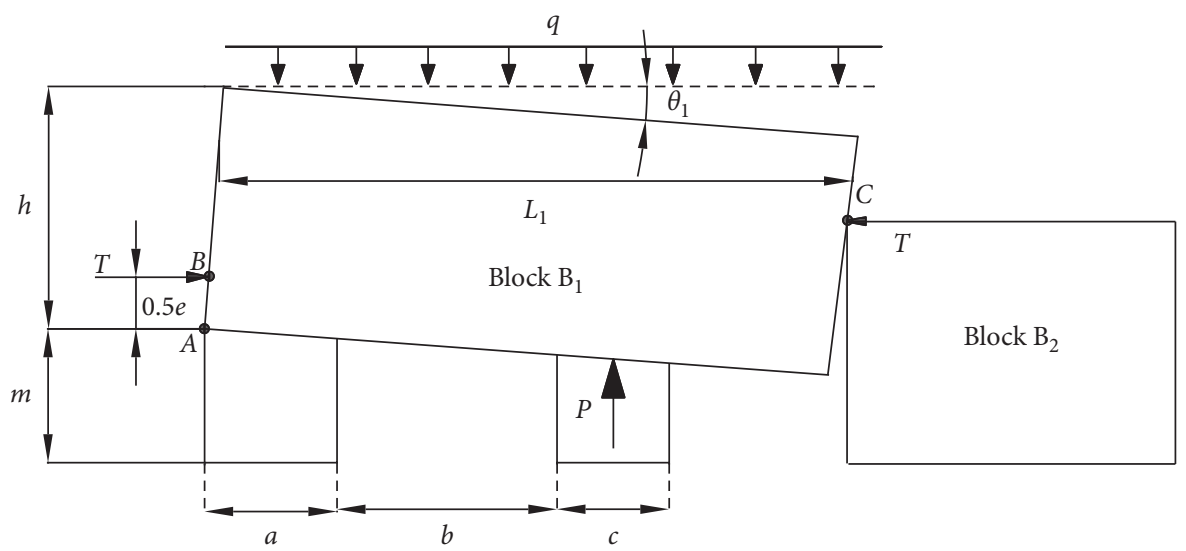

Figure 3: Mechanical model of the THAS.

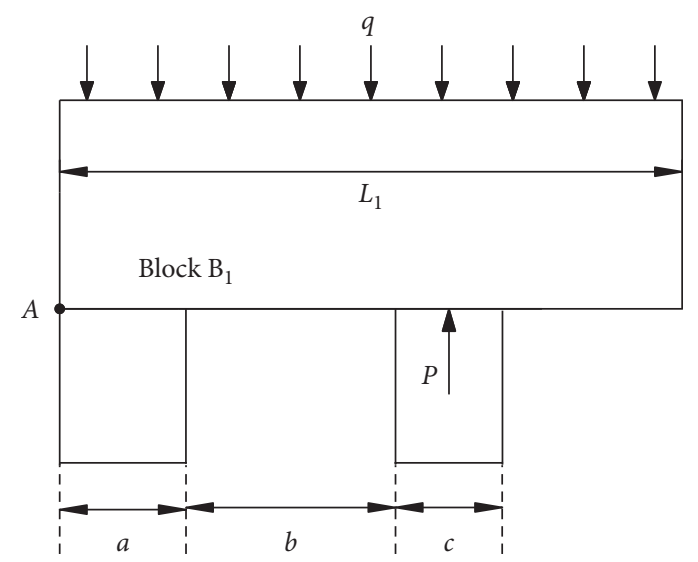

FIgURE 4: Mechanical model of the cantilever beam structure.

Table 1: Physical and mechanical parameters of coal and roof.

\begin{tabular}{|c|c|c|c|c|c|c|c|}
\hline Lithology & $\begin{array}{l}\text { Thickness } \\
\text { (m) }\end{array}$ & $\begin{array}{c}\text { Density } \\
\left(\mathrm{kN} \cdot \mathrm{m}^{-3}\right)\end{array}$ & $\begin{array}{c}\text { Modulus of elasticity } \\
(\mathrm{GPa})\end{array}$ & $\begin{array}{l}\text { Poisson's } \\
\text { ratio }\end{array}$ & $\begin{array}{l}\text { Tensile strength } \\
\text { (MPa) }\end{array}$ & $\begin{array}{c}\text { Internal friction } \\
\text { angle }\left({ }^{\circ}\right)\end{array}$ & Note \\
\hline Coal seam & 3 & 13.5 & 2.2 & 0.43 & 0.41 & 14.8 & \multirow{3}{*}{$\begin{array}{c}\text { Main roof } \\
\text { Compensated } \\
\text { load }\end{array}$} \\
\hline Siltstone & 9.07 & 24.1 & 22 & 0.27 & 4.2 & 32 & \\
\hline $\begin{array}{l}\text { Sand shale } \\
\text { interbed }\end{array}$ & 8.93 & 25.7 & 15.6 & 0.29 & 3.7 & 31 & \\
\hline
\end{tabular}

$$
a=\frac{\arctan \left[\left(r \beta Q_{0}+2 \beta^{2} M_{0} s\right) /\left(r^{2} M_{0}+\beta r Q_{0}\right)\right]}{\beta},
$$

where $E$ is the elastic modulus of main roof, $\mathrm{GPa}$; $k$ is the foundation coefficient and $k=E^{\prime} / m ; E^{\prime}$ is the elastic modulus of the coal seam and $E^{\prime}=E /\left(1-v^{2}\right) ; I$ is the bending modulus of main roof and $I=h^{3} / 12 ; M_{0}$ is bending moment above the coal wall; and $Q_{0}$ is the shear force above the coal wall. In addition, $r=\sqrt{\left(k / E^{\prime} I\right)}, s=T / E^{\prime} I, \quad \beta=(r / 2)^{1 / 2}$, $Q_{0}=q L$, and $M_{0}=q L^{2} / 2$.

According to the geological conditions of panel 5312, the parameters $z=31.7 \mathrm{~m}, L=30.6 \mathrm{~m}$, and $a=3.7 \mathrm{~m}$ can be calculated by equations (6) and (7). According to previous research [9], the rotation angle of the main roof was set at $4^{\circ}$; hence, the relationship among the roof cutting, the wall force of the cantilever beam structure, and THAS is shown in Figure 5.
As can be seen from Figure 5, whether the roof is in a cantilever beam or a THAS, reducing the length of the block by cutting the roof can play a more obvious pressure-relief effect. When the cantilever beam structure is formed after roof cutting, the minimum roof-cutting position is $L_{1}=a+b+c=8.7 \mathrm{~m}$; at this moment, the roof cantilever length is $0 \mathrm{~m}$ and the wall force is $3633 \mathrm{kN}$. While, when the wall force is $3633 \mathrm{kN}$, the THAS is formed after roof cutting and the cutting position is $13 \mathrm{~m}$, and the roof cantilever length is $4.3 \mathrm{~m}$. According to the analysis of Section 2.2, the longer the cantilever length is, the easier the THAS will be formed. Considering the field engineering, the cutting position should not be too close to the roadway because the blasting impact and the roof subsidence after presplit blasting will cause serious deformation of surrounding rocks, which is not conducive to the stability of the roadway. Hence, it can be concluded that the THAS is more conducive to the stability of the rock surrounding the GSE in 


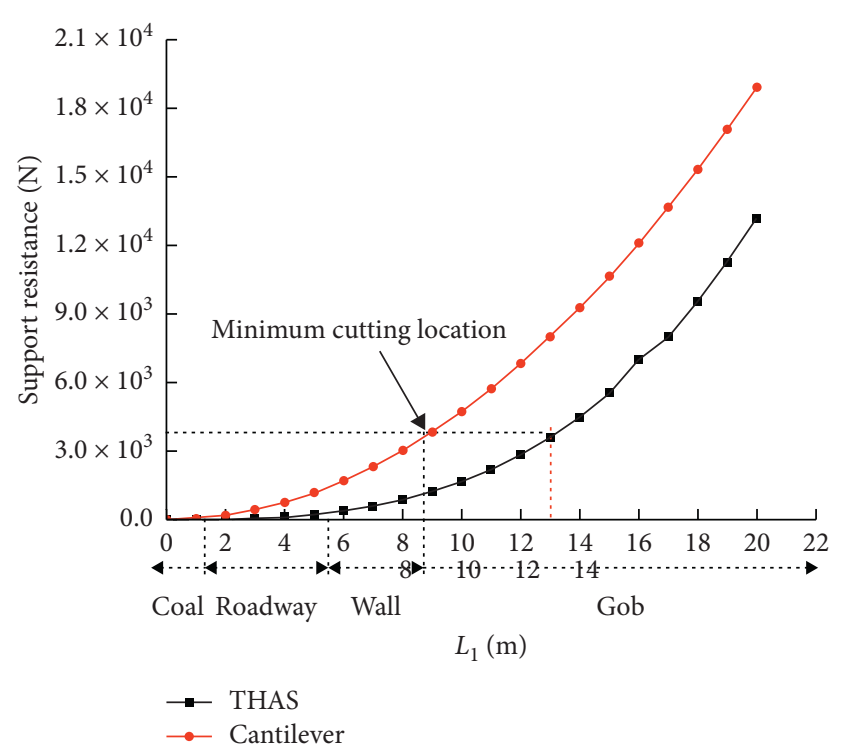

FIGURE 5: Relationship between the roof cutting and the wall force of different overburden structure.

panel 5312 and that the best position of roof presplitting is about $5 \mathrm{~m}$ outside the roadway.

3.2. Analysis of Key Parameters of GSER. According to equation (5), many factors such as the coal-seam thickness, overlying load, key block movement, and roadway width affect the wall force. In this study, the objective geological factors (e.g., coal seam thickness and overlying load) were not considered. Instead, we studied the relationship of the key-block rotation angle, the roadway width (wall width), and the wall force.

Figure 6 shows the variation curve of the relationship among the rotation angle of the key block, roadway width (wall width), and the wall force. It can be concluded that the wall force increases with an increase in the rotation angle of the key block, whereas it decreases with an increase in the roadway width. Moreover, the rotation angle of $\theta_{1}$ decreases with increases in the stiffness of the wall and in the coal seam because it is obviously affected by these parameters, and the stress in the rock surrounding the roadway increases with an increase in $\theta_{1}$. Hence, bolt support at the coal side can be adopted, or high-strength wall-filling material can be used, thus increasing the bearing capacity and effectively improving the stability of the rock surrounding the roadway. In addition, a decrease in the wall force will inevitably lead to an increase in the coal force of the roadway according to the mechanical balance for the $B_{1}$ block, which leads to large deformation and is not conducive to controlling the rock surrounding the roadway. Hence, it is necessary to design a reasonable roadway width for GSE stability.

\section{Analysis of Numerical Simulation}

4.1. Establishment of the Numerical Model. In order to further reveal the influence of roof presplitting and cutting technology on the stress and deformation of the surrounding rock for GSER, UDEC numerical simulation was used to study the pressure-relief effects of the roof cutting angle and cutting position. As a result, the best roof-cutting angle and cutting position were obtained. Hence, a total of 32 different combination schemes were designed by setting different cutting angles such as $0^{\circ}, 10^{\circ}, 15^{\circ}$, and $25^{\circ}$ and different cutting positions such as $1 \mathrm{~m}, 3 \mathrm{~m}, 5 \mathrm{~m}, 7 \mathrm{~m}, 9 \mathrm{~m}, 11 \mathrm{~m}, 13 \mathrm{~m}$, and $15 \mathrm{~m}$. The sizes of the simulation model and the roadway were $200 \mathrm{~m}$ (length) $\times 81 \mathrm{~m}$ (height) and $4.5 \mathrm{~m}$ (width) $\times 3 \mathrm{~m}$ (height), respectively, and the wall width was $2.7 \mathrm{~m}$. Moreover, the boundary conditions of the bottom and both sides of this model were full-displacement constraints and horizontal-displacement constraints, respectively, and the model top applied 12.5 MPa vertical stress to compensate for the failed simulation strata. The Mohr-Coulomb model was adopted for the coal and rock mass, and the strain-hardening model was adopted for the wall. An overview of the simulation model and its parameters are shown in Figure 7.

4.2. Analysis of the Angle Effect of Roof Cutting. The simulation results of the 32 aforementioned schemes revealed that the roof structure changes similarly with the cuttingangle variation at different cutting positions. Hence, the cutting position of $5 \mathrm{~m}$ was chosen, and the structure variations with different cutting angles as shown in Figure 8 were analyzed.

The different cutting angles had different effects on the movement of key blocks after roof cutting. It was easier for the $\mathrm{B}_{2}$ block to be fully cut down to the horizontal state with an increase in the cutting angle. When the cutting angle was less than $15^{\circ}$, as shown in Figures 8 (a) and $8(\mathrm{~b})$, the influence of roof cutting on the overburden structure was small, the movement of overburden is slight, and the pressure-relief effect was not obvious. When the cutting angle was greater than $15^{\circ}$ (Figure $8(\mathrm{~d})$ ), the $\mathrm{B}_{2}$ block was completely cut down and was relatively isolated; therefore, it could not make contact with the cantilever of the $B_{1}$ block to form a stable THAS. However, when the cutting angle was $15^{\circ}$, as shown in Figure 8(c), the $\mathrm{B}_{2}$ block was cut down, and the $\mathrm{B}_{1}$ block was squeezed and occluded to form a THAS, which can have an obvious pressure-relief effect. Hence, the optimal angle of roof cutting for pressure relief is $15^{\circ}$ for these simulation conditions.

4.3. Analysis of the Position Effect of Roof Cutting. Accordingly, in order to study the position effect of roof cutting for pressure relief, the cutting angle of $15^{\circ}$ was chosen, and the structure variations with different cutting positions as shown in Figure 9 are analyzed.

When the cutting angle was $15^{\circ}$, the blocks with different cutting positions can be squeezed and bitten; however, the pressure-relief effect for the main roof is different. When the cantilever length is less than $5 \mathrm{~m}$ (Figures 9(a) and 9(b)), the key block can form an articulated structure, but the $\mathrm{B}_{2}$ block above the goaf cannot fully move, which affects the stability of the articulated structure and the stress of the surrounding rock for GSE. When the cantilever length is $5 \mathrm{~m}$, as shown in Figure $9(\mathrm{c})$, the $\mathrm{B}_{2}$ block can be sufficiently cut down to form 


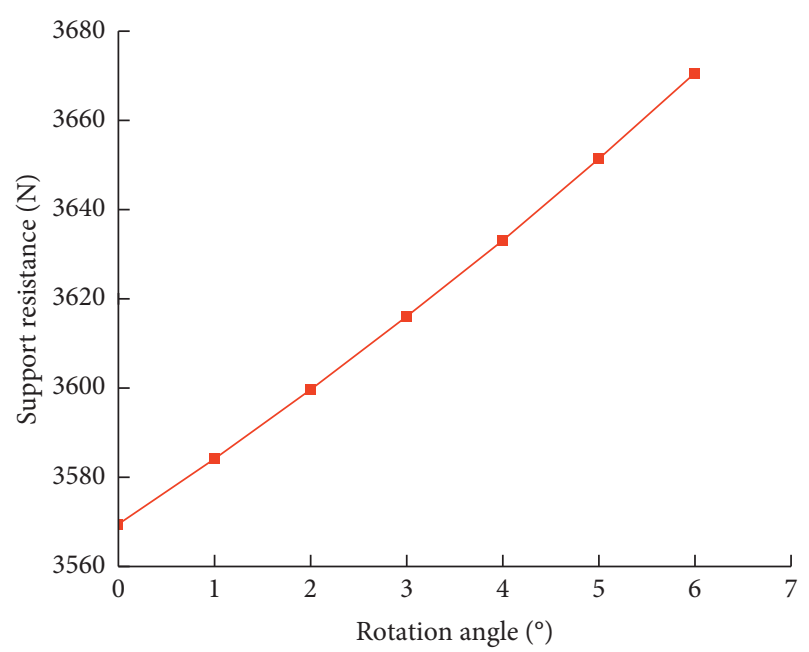

(a)

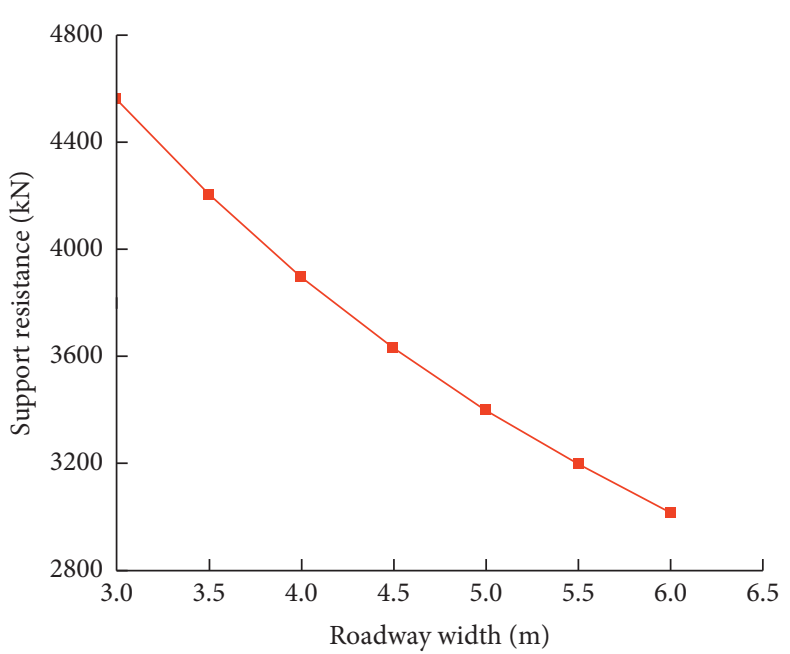

(b)

FIGURE 6: Relationship among (a) rotation angle of the key block and the wall force and (b) roadway width and wall force.

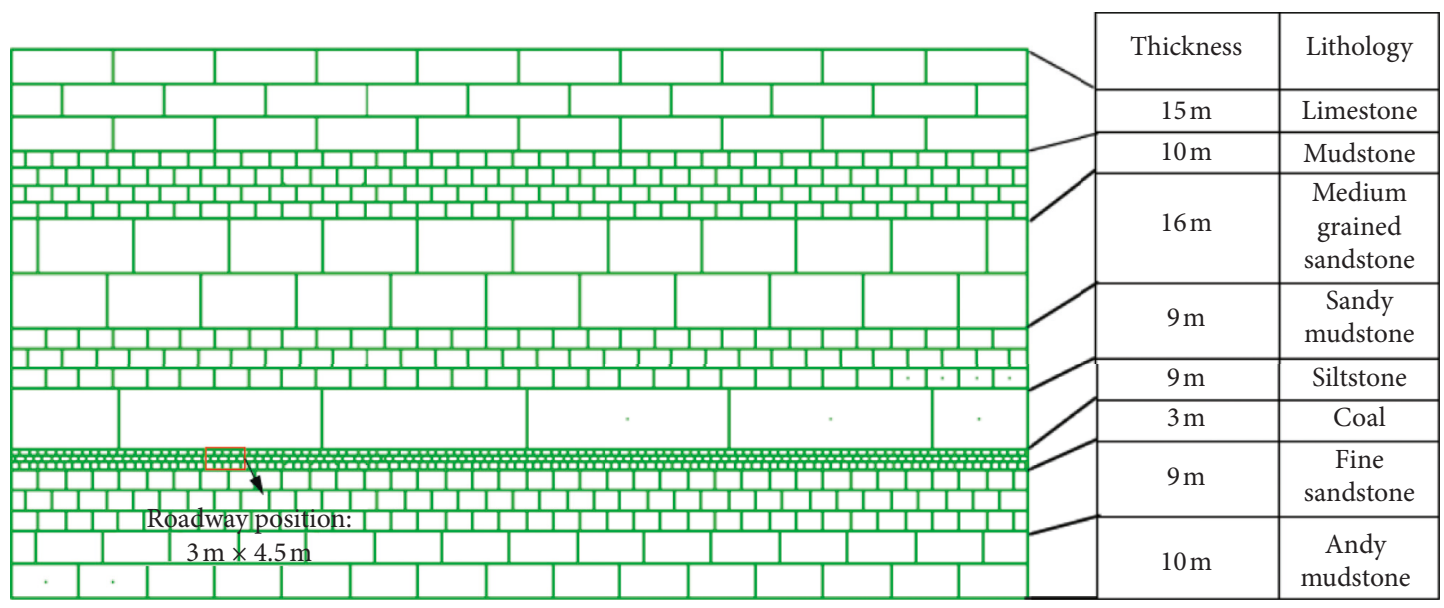

FIGURE 7: Numerical model.

a stable three-hinged arch structure with the $\mathrm{B}_{1}$ block. In this case, the pressure-relief effect for the surrounding rock is remarkable, and the deformation of the coal side can be effectively controlled. When the cantilever length is greater than $5 \mathrm{~m}$ (Figure $9(\mathrm{~d})$ ), the key $\mathrm{B}_{2}$ block can still be cut down sufficiently, although the increase in cantilever length will load more pressure to the rock surrounding the roadway. Hence, the optimal position of roof cutting for pressure relief is a cantilever length of $5 \mathrm{~m}$ under these simulation conditions. This result is essentially consistent with the theoretical analysis results of $4.3 \mathrm{~m}$, which indicates that the numerical simulation design is more reasonable.

4.4. Effect of THAS on Rock Surrounding the GSE. The THAS of the main roof is beneficial to the stability of rock surrounding the GSE; however, THAS formation is closely related to the cutting angle and the cutting position. Through the study and analysis of 32 schemes, it was found that the critical values for THAS formation are a cutting angle of $10^{\circ}$, cutting position of $13 \mathrm{~m}$, angle of $15^{\circ}$, and position of $5 \mathrm{~m}$, as shown in Figure 10. The displacement variations of the coal side of the GSE before and after the THAS formation are depicted in Figure 11.

As shown in Figures 10(a), 10(c), and 11, the THAS was not formed after roof cutting, and the stability of the main roof above the roadway was poor, causing serious deformation to the coal side and floor heaving of the GSE, which seriously affect the normal use of the roadway. However, Figures 10(b), 10(d), and 11 show THAS formation, in which the roadway deformation at the coal side is relatively uniform.

The wall beside the roadway can provide effective support for the roadway and can share part of the load for the solid coal body of the roadway. Hence, the stress concentration in the wall is obviously reduced after the THAS formation. As shown in Figures 10(c) and 10(d), the vertical stress in the wall was $25.3 \mathrm{MPa}$ before the THAS formation but fell to $18.9 \mathrm{MPa}$ with a decrease rate of $25 \%$ after the structure formed. Hence, to alleviate the pressure and control the deformation of the surrounding rock, it is of 


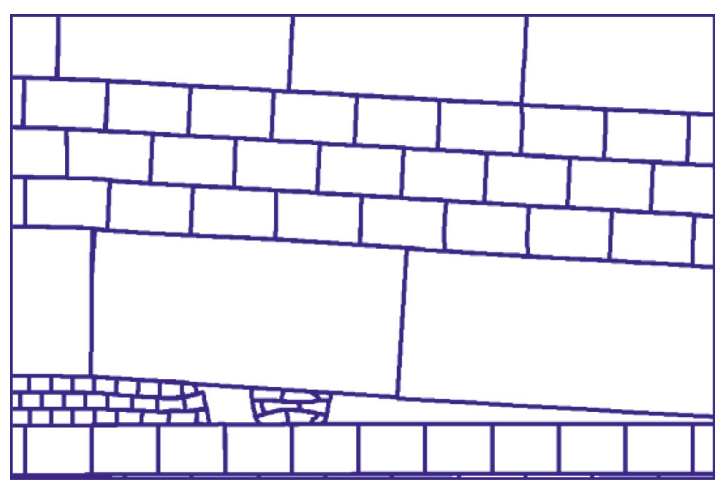

(a)

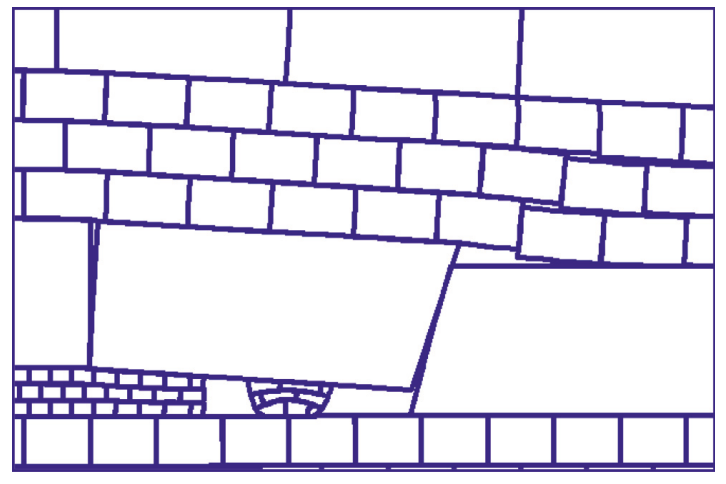

(c)

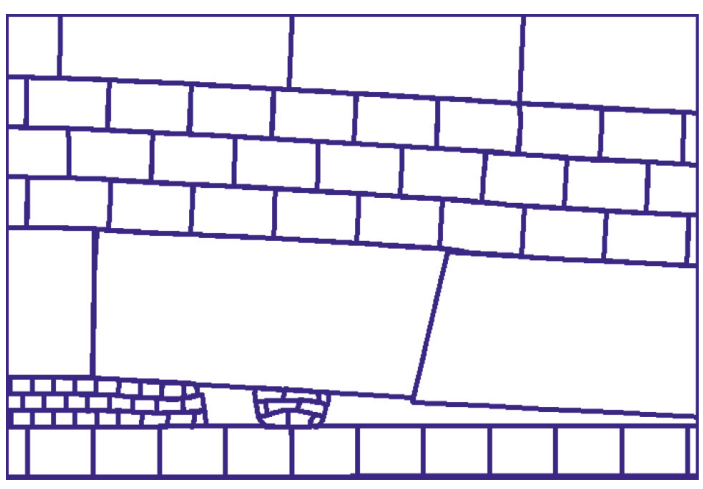

(b)

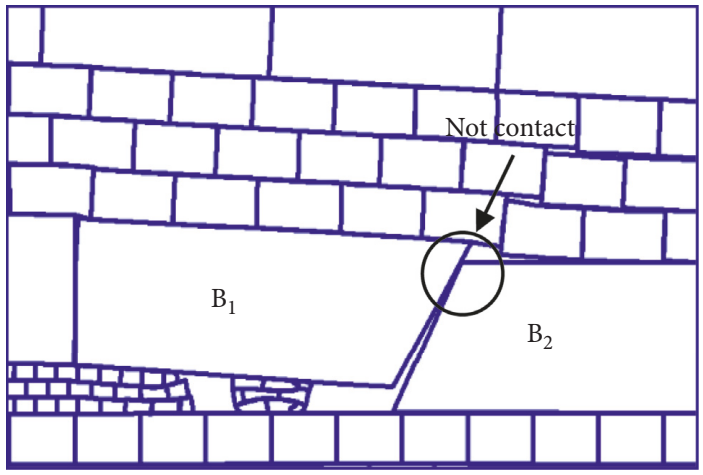

(d)

FIGURE 8: Variations of the roof structure with different cutting angles: (a) $0^{\circ}$, (b) $10^{\circ}$, (c) $15^{\circ}$, and (d) $25^{\circ}$.

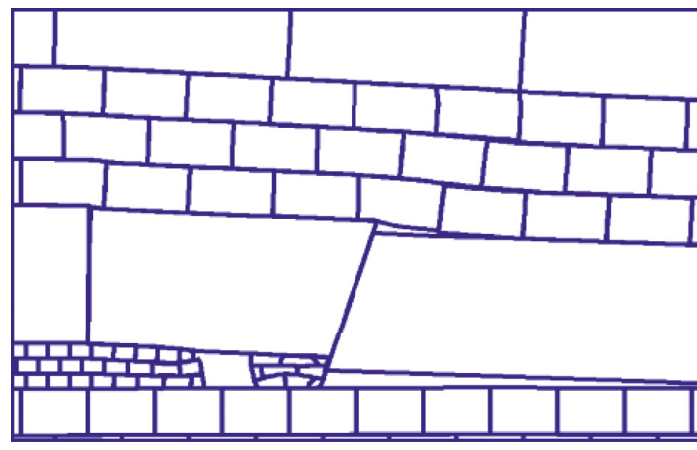

(a)

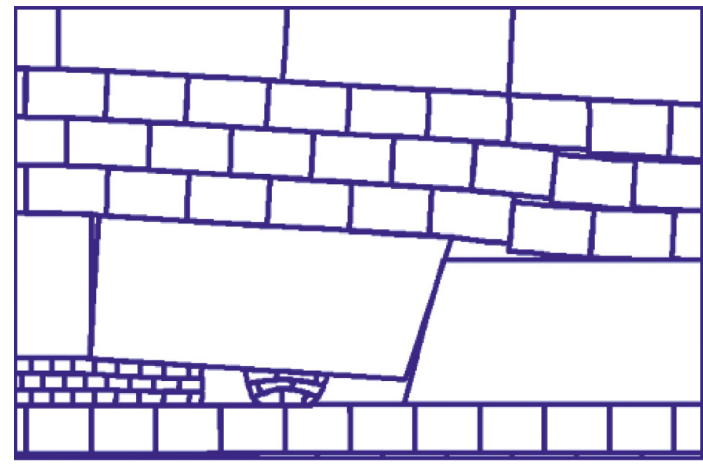

(c)

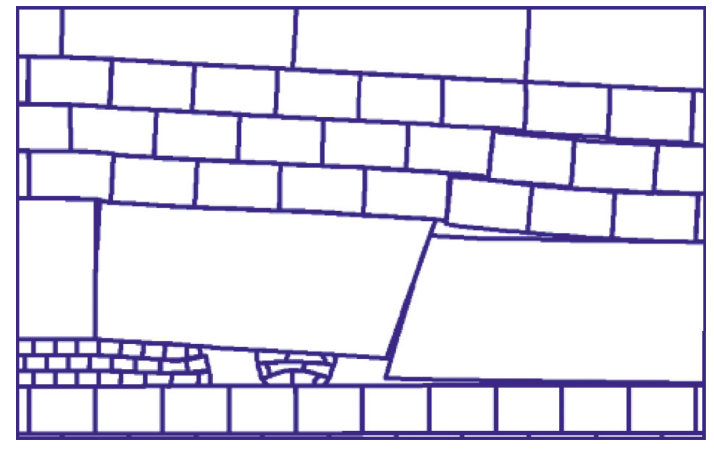

(b)

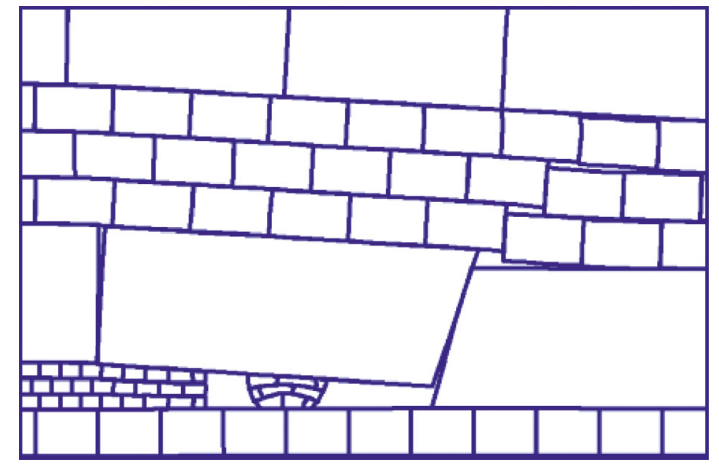

(d)

Figure 9: Variations of roof structure with different cutting positions: (a) $1 \mathrm{~m}$, (b) $3 \mathrm{~m}$, (c) $5 \mathrm{~m}$, and (d) $7 \mathrm{~m}$. 


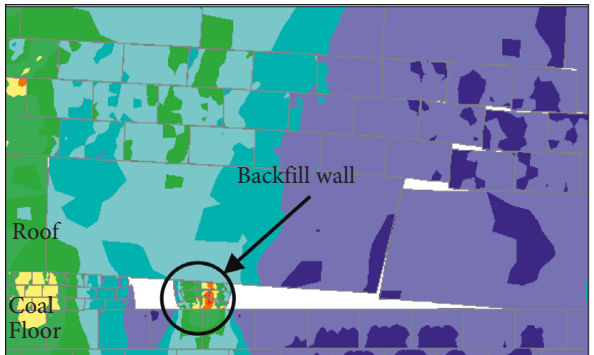

(a)

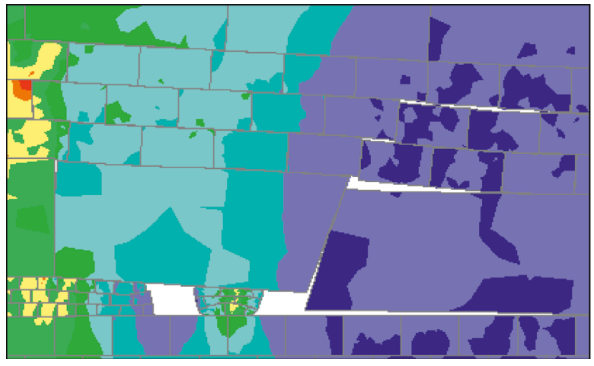

(c)
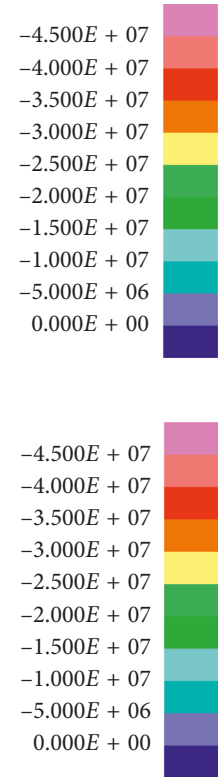

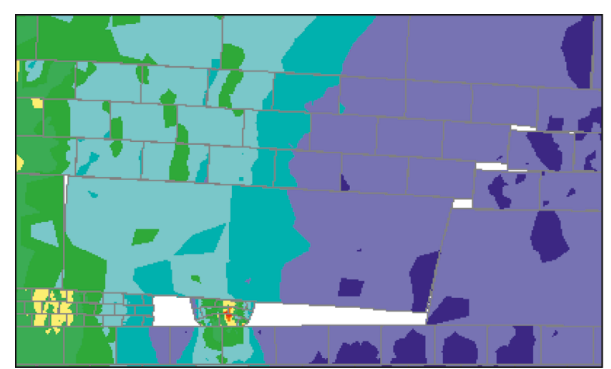

$-4.500 E+07$ $-4.000 E+07$ $-3.500 E+07$ $-3.000 E+07$ $-2.500 E+07$ $-2.000 E+07$ $-1.500 E+07$ $-1.000 E+07$ $-5.000 E+06$ $0.000 E+00$

(b)

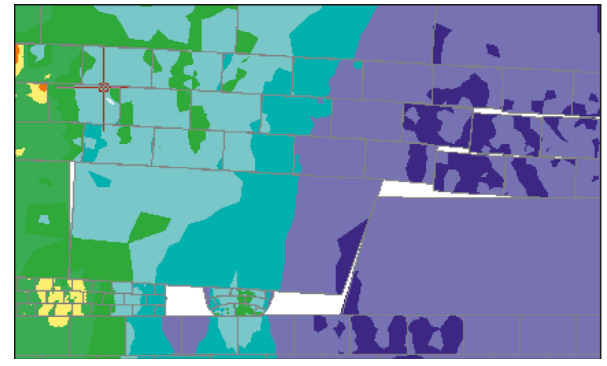

$-4.500 E+07$

$-4.000 E+07$

$-3.500 E+07$

$-3.000 E+07$

$-2.500 E+07$

$-2.000 E+07$

$-1.500 E+07$

$-1.000 E+07$

$-5.000 E+06$

$0.000 E+00$

(d)

FIGURE 10: Stress distribution of surrounding rock before and after the THAS formation. (a) Cutting angle $10^{\circ}$ and position $11 \mathrm{~m}$, (b) cutting angle $10^{\circ}$ and position $13 \mathrm{~m}$, (c) cutting angle $15^{\circ}$ and position $3 \mathrm{~m}$, and (d) cutting angle $15^{\circ}$ and position $5 \mathrm{~m}$.

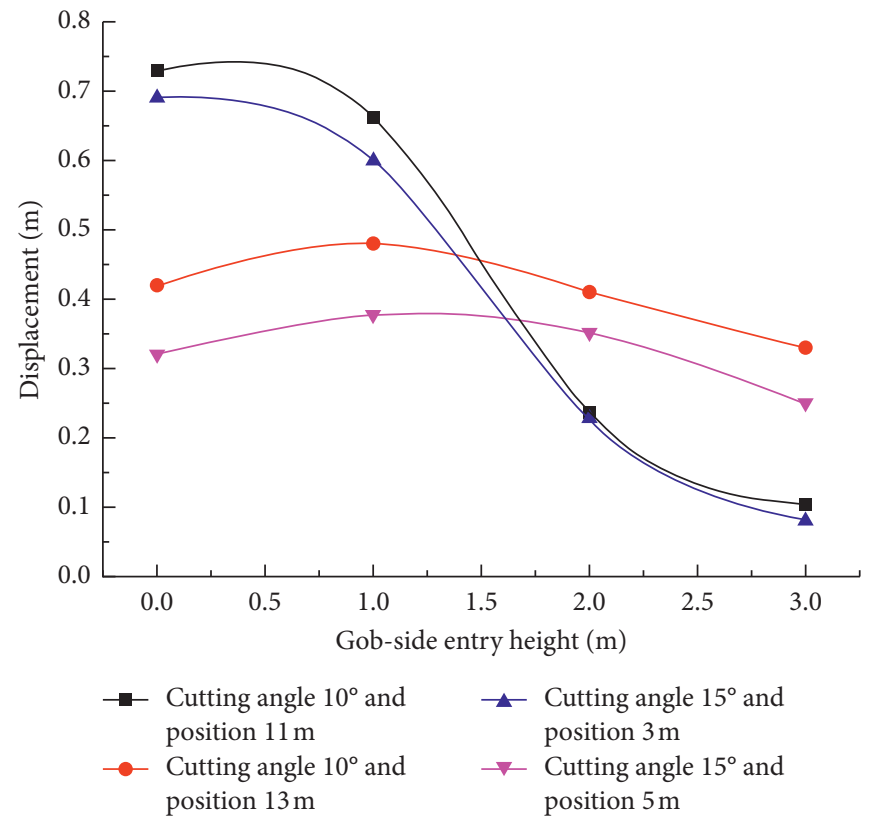

FIGURE 11: Displacement variation of coal side of GSER before and after the THAS formation.

great significance to reasonably choose the cutting angle and cutting position.

The vertical stress of the wall in Figure 10(b) is obviously less than that of the wall in Figure 10(d), and the deformation of the former is less than that of the latter, as shown in Figure 11. Hence, the optimal scheme of roof cutting was determined to be a $15^{\circ}$ cutting angle and a $5 \mathrm{~m}$ cutting position. Moreover, referring to the previous studies [35-38], it can be found that the simulation results from this paper are basically consistent with the results from those, which proves the scientificity of the simulation results and the rationality of the simulation methods to a certain extent.

4.5. Comparative Analysis of Pressure-Relief Effect between Roof Cutting and Non-Roof-Cutting. According to the aforementioned optimal scheme of roof cutting (cutting angle of $15^{\circ}$ and cutting position of $5 \mathrm{~m}$ ), the vertical stress distribution and its variations of roof cutting and non-roof-cutting were 


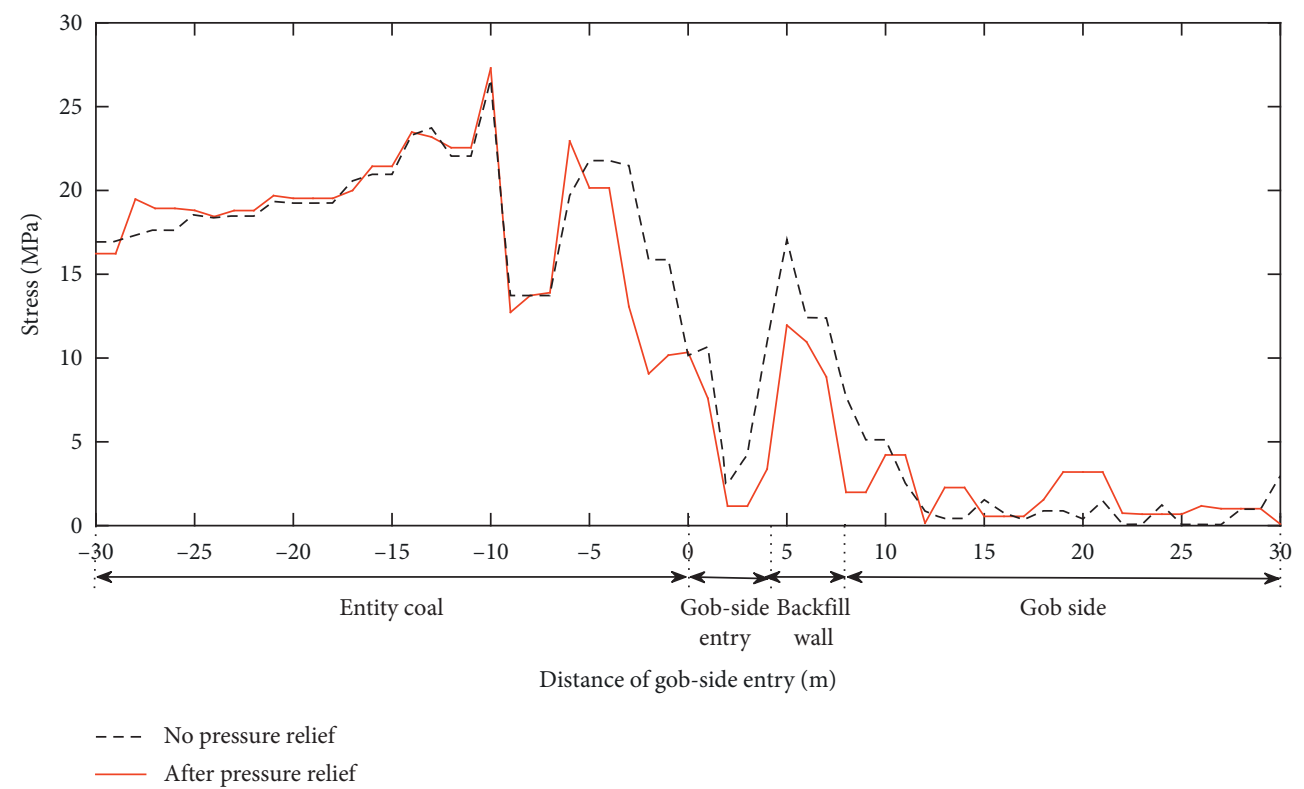

FIgURE 12: Stress distribution and its variations of roof cutting and non-roof-cutting.

studied by setting up two monitoring lines $0.5 \mathrm{~m}$ above the roadway, as shown in Figure 12.

Because of the roadway excavation and face mining, a stress concentration zone occurs in the solid coal and in the wall of the roadway with and without roof cutting. However, the roadway is in the stress relaxation zone between the two zones of stress concentration. The vertical stress of the wall without roof cutting was $17.9 \mathrm{MPa}$, whereas that of the wall with roof cutting was $11.9 \mathrm{MPa}$, showing a $33 \%$ decrease. Moreover, compared with that without roof cutting, the stress concentration zone moved forward after roof cutting, and the influence range decreased. Hence, the pressure-relief effect with roof cutting is obvious.

Figure 13 shows the displacement variations of the rock surrounding of the roadway with and without roof cutting. Before roof cutting, the stress concentration was large in the wall and in the solid side of the roadway owing to the high strength and stiffness of the main roof, resulting in obvious deformation of the roadway. After roof cutting, the main roof inside the cutting line rotated and sank. In addition, a THAS formed with the block outside the cutting line, which decreased the stress of the surrounding rock and controlled the deformation of the roadway. Among factors, the pressure-relief effect of the roadway at the solid coal side was the most remarkable.

\section{Field Observations}

Based on the geological conditions of panel 5312 in the Jining No. 3 coal mine, the optimal cutting position and angle of presplitting blasting for pressure relief were obtained. In order to further explain the effects of roof cutting and pressure relief, this section discusses on-site monitoring performed during the mining process of panel 5312 and analyzes the force of the roof anchor cable and the variation of the support stress.

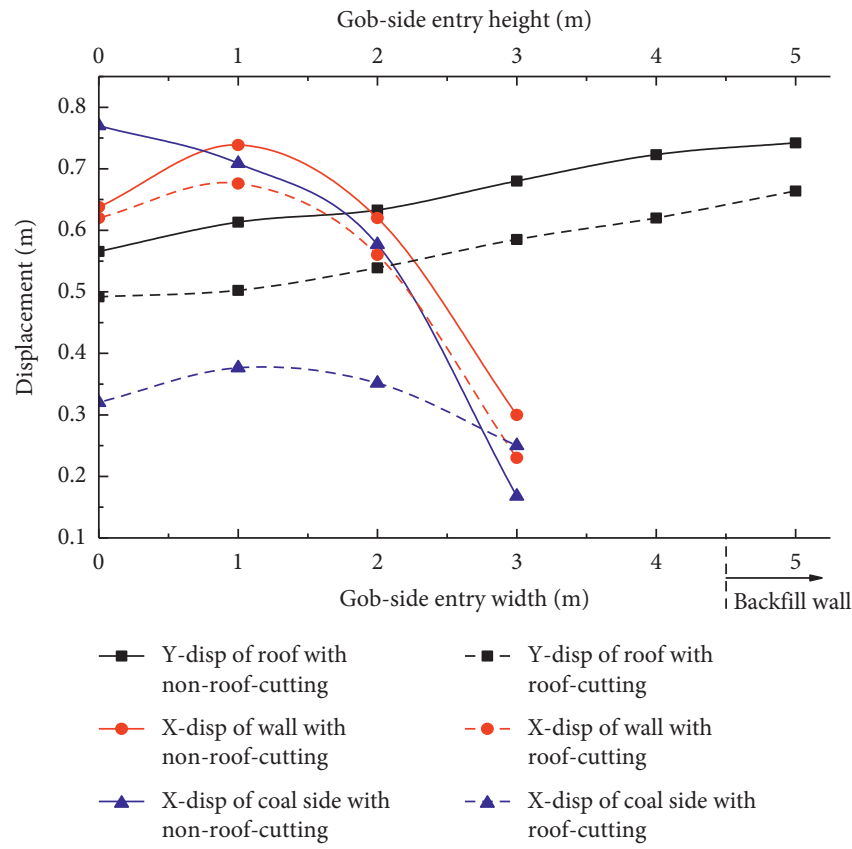

FIgURE 13: Displacement variations of surrounding rocks of the roadway with roof cutting or non-roof-cutting.

5.1. Force Monitoring of Roof Anchor Cable. According to the objectives of this study, a total of seven anchor-cable force sensors marked as A1-A7 were installed in the target roadway. The distances between the sensors and the open-off cut were $30 \mathrm{~m}, 150 \mathrm{~m}, 215 \mathrm{~m}, 230 \mathrm{~m}, 350 \mathrm{~m}$, $450 \mathrm{~m}$, and $650 \mathrm{~m}$ for $\mathrm{A} 1$ to $\mathrm{A} 7$, respectively, and the anchor-cable force was monitored by using a remote online-monitoring system. Figure 14 describes the force variations of A2, A4, and A7 anchor cables with typical mining conditions. 


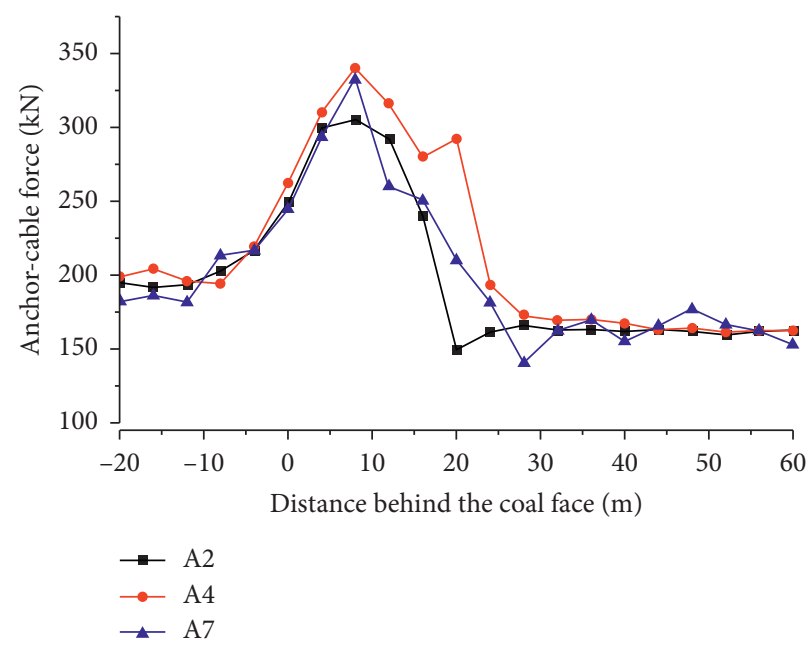

Figure 14: Monitoring curve of anchor-cable force.

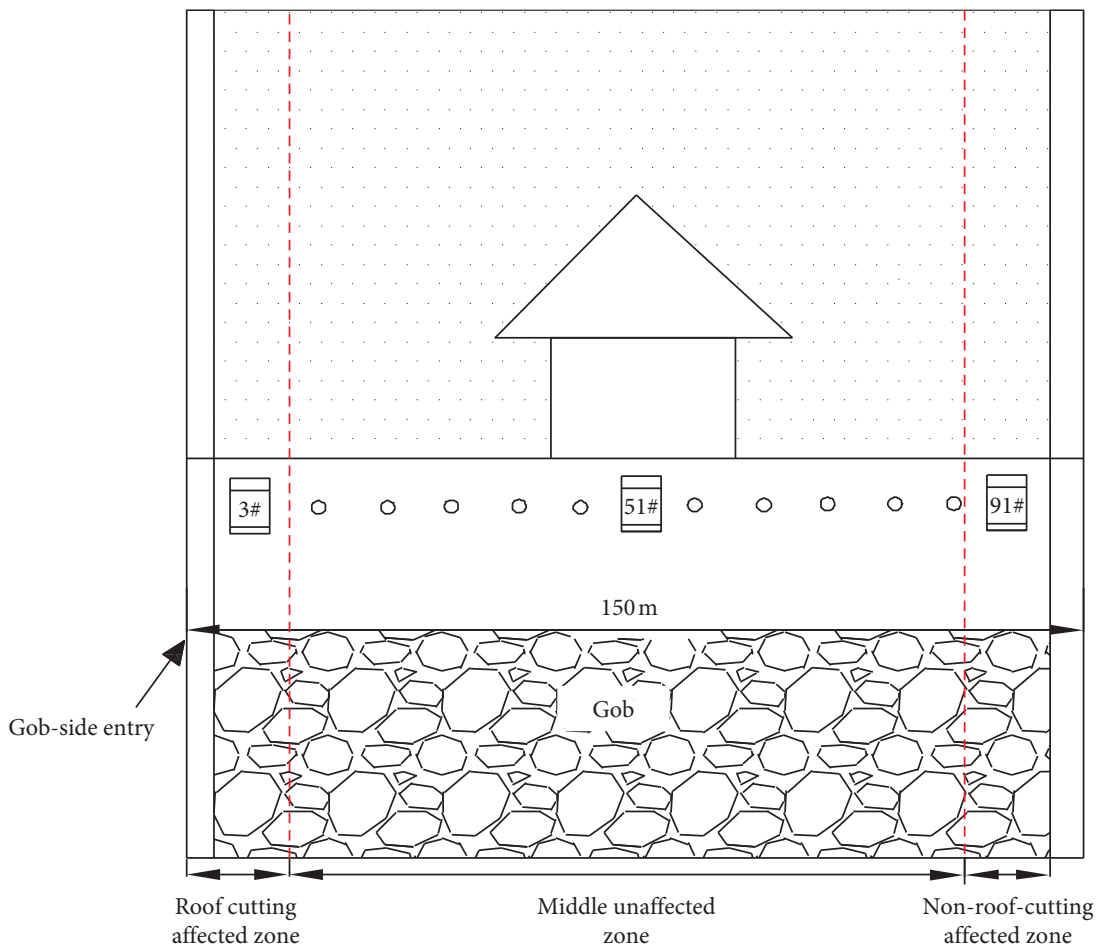

FIGURE 15: Monitoring points of support stress.

The force variations of the roof anchor cables in the three monitoring positions were similar, and the influence range of mining dynamic pressure was essentially stable at $30-$ $35 \mathrm{~m}$. The force of the anchor cable began to increase about $10 \mathrm{~m}$ between the monitoring point and the working face. The growth rate gradually intensified. When the distance between the face and the point was about $8 \mathrm{~m}$, the force of anchor cable reached its peak value and then rapidly decreased. When the working face pushed through the monitoring point for $30 \mathrm{~m}$, the force essentially stabilized at $150 \mathrm{kN}$, indicating that the roof of the retaining roadway had been cut down along the presplitting face to successfully relieve the pressure.
5.2. Stress Monitoring of Supports. During the mining process of panel 5312, a total of 100 hydraulic supports of type ZY7200-18.5/34 were selected. The rated working resistance of the support was $7200 \mathrm{kN}(40 \mathrm{MPa})$, and the maximum support height was $3400 \mathrm{~mm}$. The stress monitoring points of the supports were arranged as shown in Figure 15. A stress-monitoring point was arranged in increments of eight supports, i.e., on support Nos. 3, 11, 19, 27, 35, 43, 51, 59, 67, $75,83,91$, and 99 for on-line real-time monitoring of the stress data.

According to the aforementioned monitoring scheme, the stope can be divided into three areas: the roof-cuttingaffected zone, the unaffected area in the middle, and the zone 


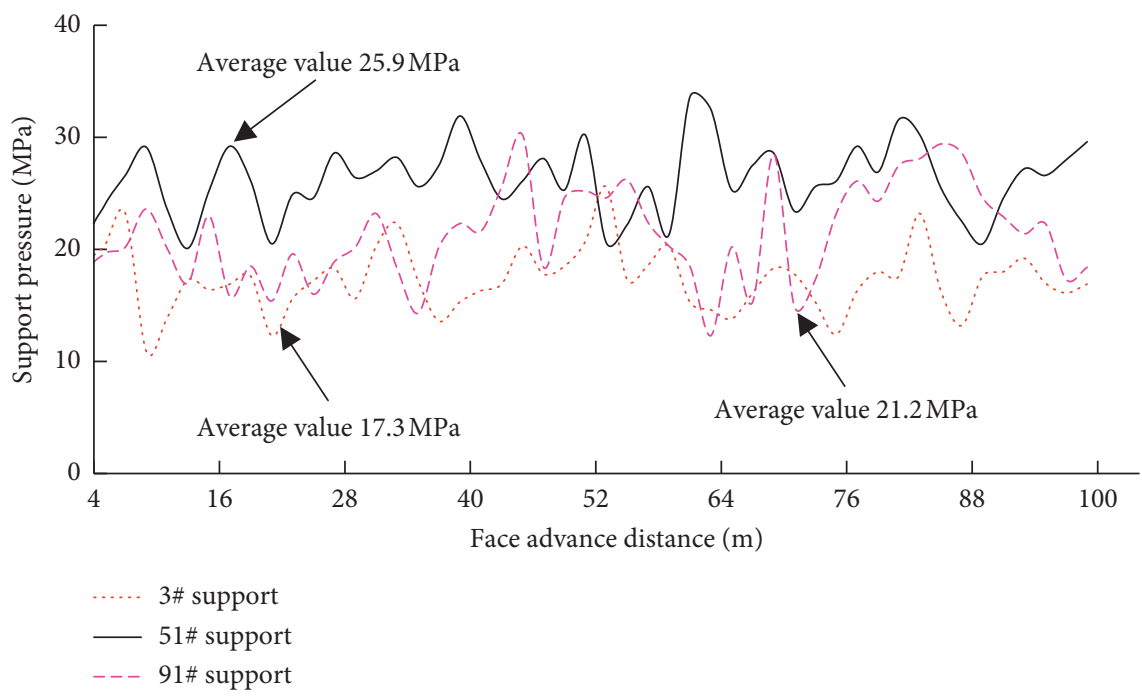

FIgURE 16: Variation curve of support load.

TABLE 2: Statistics of weighting and support stress.

\begin{tabular}{lccc}
\hline No. & First weighting $(\mathrm{m})$ & Periodic weighting (m) & $\begin{array}{c}\text { Support stress } \\
(\mathrm{MPa})\end{array}$ \\
\hline $3 \#$ & 50 & 31 & 17.3 \\
$51 \#$ & 40 & 19 & 25.9 \\
$91 \#$ & 44 & 26 & 21.2 \\
\hline
\end{tabular}

not affected by roof cutting. Three hydraulic supports, Nos. 3,51 , and 91, were selected to monitor and analyze the rock pressure. Among them, support No. 3 was located in the zone not affected by roof cutting; No. 51 was located in the middle unaffected zone, and No. 91 was located in the roofcutting-affected zone.

Figure 16 and Table 2 show statistical curves of the support load and the weighting step. The first weighting and periodic weighting of support No. 3 , in the zone not affected by roof cutting, were $44 \mathrm{~m}$ and $26 \mathrm{~m}$, respectively; those of No. 91 , in the zone affected by roof cutting, were $50 \mathrm{~m}$ and $31 \mathrm{~m}$, respectively. The two parameters of the latter are obviously larger than those of the former, indicating that a stable THAS formed between the collapsed and noncollapsed roof after roof cutting, and that the rotary deformation of the noncollapsed roof was small. This prevented the main roof from easily breaking; that is, the breaking span of the main roof increased. The decrease in support resistance indicates that a caving roof provides a certain degree of support for a noncaving roof and that the pressure of the noncaving roof on the rock surrounding the GSE decreases correspondingly.

\section{Conclusions}

Regarding the pressure-relief effects of hard roof blasting and cutting, the factors selected for the roof cutting position and its angle obviously affects the surrounding rock stability of the GSE. In this study, which focused on controlling the large deformation of this rock, the following results were obtained:
(1) Based on the analysis of the overlying structure and pressure-relief principle caused by roof cutting, a mechanical model of a THAS is established. It was determined that the overlying rock can form a stable THAS after roof blasting and cutting. In addition, the wall stress and the coal-wall displacement were small, which indicates that roof blasting and cutting has obvious effects of pressure relief.

(2) Taking panel 5312 of the Jining No. 3 coal mine as the engineering background, the relationship among the rotation angle of the key block, the width of roadway, and the wall force beside the roadway was studied. The wall force was found to increase with an increase in the rotation angle of the key block but decreased with an increase in the roadway width.

(3) The effects of roof-cutting position and angle were studied, with optimal results found to be $5 \mathrm{~m}$ and $15^{\circ}$, respectively. Finally, on-site monitoring of the anchor-cable force and the support force in panel 5312 of the Jining No. 3 coal mine was used to verify the pressure relief effect after roof blasting and cutting.

These study results can provide a theoretical basis for reasonable technical means and optimization of supporting parameters in field observation. Moreover, they have important application value for roof cutting and pressure relief in GSER technology.

\section{Data Availability}

The data used to support the findings of this study are available from the corresponding author upon request.

\section{Conflicts of Interest}

The authors declare that there are no conflicts of interest. 


\section{Acknowledgments}

This study was funded by the National Natural Science Foundation of China (nos. 51574155 and 51804182), Science and Technology Development Plan of Tai'an (no. 2018GX0045), Shandong Provincial Natural Science Foundation (no. ZR2019BEE065), Scientific Research Foundation of Shandong University of Science and Technology for Recruited Talents (no. 2015RCJJ057), and Shandong Provincial Key R\&D Plan (Public Welfare Special Program) of China (no. 2017GGX20125).

\section{References}

[1] Q. Wang, M. He, J. Yang, H. Gao, B. Jiang, and H. Yu, "Study of a no-pillar mining technique with automatically formed gob-side entry retaining for longwall mining in coal mines," International Journal of Rock Mechanics and Mining Sciences, vol. 110, no. 1, pp. 1-8, 2018.

[2] L. S. Jiang, P. Kong, J. M. Shu, and K. G. Fan, "Numerical analysis of support designs based on a case study of longwall entry," Rock Mechanics and Rock Engineering, pp. 1-12, 2019.

[3] P. Wang, L. S. Jiang, X. Y. Li, G. P. Qin, and E. Y. Wang, "Physical simulation of mining effect caused by A fault tectonic," Arabian Journal of Geosciences, vol. 11, no. 23, p. 741, 2018.

[4] P. Wang, L. S. Jiang, X. Y. Li, P. Q. Zheng, and G. P. Qin, "Effects of strength weakening and interface slipping on rock mass with different dip angle structure planes," Acta Geodynamica et Geomaterialia, vol. 15, no. 4, pp. 329-338, 2018.

[5] S. Yan, T. Liu, J. Bai, and W. Wu, "Key parameters of gob-side entry retaining in a gassy and thin coal seam with hard roof," Processes, vol. 6, no. 5, p. 51, 2018.

[6] J. G. Ning, X.S. Liu, J. Tan, Q.H. Gu, Y. L. Tan, and J. Wang, "Control mechanisms and design for a "coal-backfill-gangue" support system for coal mine gob-side entry retaining," International Journal of Oil Gas and Coal Technology, vol. 18, no. 3-4, pp. 444-466, 2018.

[7] D. W. Yang, Z. G. Ma, and F. Z. Qi, “Optimization study on roof break direction of gob-side entry retaining by roof break and filling in thick-layer soft rock layer," Geomechanics and Engineering, vol. 13, no. 2, pp. 195-215, 2017.

[8] X. Li, M. Ju, Q. Yao, J. Zhou, and Z. Chong, "Numerical investigation of the effect of the location of critical rock block fracture on crack evolution in a gob-side filling wall," Rock Mechanics and Rock Engineering, vol. 49, no. 3, pp. 1041-1058, 2016.

[9] G. C. Zhang, Y. L. Tan, S. J. Liang, and H.-G. Jia, "Numerical estimation of suitable gob-side filling wall width in a highly gassy longwall mining panel," International Journal of Geomechanics, vol. 2018, no. 8, Article ID 04018091, 2018.

[10] M. G. Qian, Rock Stratum Control and the Scientific Collection of Coal, China University of Mining and Technology Press, Xuzhou, China, 2011.

[11] Z. Zhang, J. Xu, W. Zhu, and Z. Shan, "Simulation research on the influence of eroded primary key strata on dynamic strata pressure of shallow coal seams in gully terrain," International Journal of Mining Science and Technology, vol. 22, no. 1, pp. 51-55, 2012.

[12] X. Wang, J. Xu, W. Zhu, and Y. Li, "Roof pre-blasting to prevent support crushing and water inrush accidents," International Journal of Mining Science and Technology, vol. 22, no. 3, pp. 379-384, 2012.
[13] W. X. Zheng, Q. W. Bu, and Y. Q. Hu, "Plastic failure analysis of roadway floor surrounding rocks based on unified strength theory," Advances in Civil Engineering, vol. 2018, Article ID 7475698, 10 pages, 2018.

[14] Y. Pan, Z. Q. Wang, and A. W. Li, "Analysis of hard roof deflection, bending moment and energy change during the first fracture," Chinese Journal of Rock Mechanics and Engineering, vol. 31, no. 1, pp. 32-41, 2012.

[15] Z. Li, J. Xu, J. Ju, W. Zhu, and J. Xu, "The effects of the rotational speed of voussoir beam structures formed by key strata on the ground pressure of stopes," International Journal of Rock Mechanics and Mining Sciences, vol. 108, pp. 67-79, 2018.

[16] M. G. Qian, X. X. Miao, and J. L. Xu, Theory of Key Stratum in Ground Control, China University of Mining and Technology Press, Beijing, China, 2010.

[17] J. W. Guo and J. W. Zhao, "The study on the breaking rule and control mechanism of gob-side entry retaining of the lower roof," Journal of Mining \& Safety Engineering, vol. 29, no. 6, pp. 802-807, 2012.

[18] Z. Zhang, N. Zhang, H. Shimada, T. Sasaoka, and S. Wahyudi, "Optimization of hard roof structure over retained goaf-side gateroad by pre-split blasting technology," International Journal of Rock Mechanics and Mining Sciences, vol. 100, pp. 330-337, 2017.

[19] J. Ning, J. Wang, L. Jiang, N. Jiang, X. Liu, and J. Jiang, "Fracture analysis of double-layer hard and thick roof and the controlling effect on strata behavior: a case study," Engineering Failure Analysis, vol. 81, pp. 117-134, 2017.

[20] M. C. He, S. Y. Chen, Z. B. Guo, J. Yang, and Y. B. Gao, "Control of surrounding rock structure for gob-side entry retaining by cutting roof to release pressure and its engineering application," Journal of China University of Mining \& Technology, vol. 46, no. 5, pp. 959-969, 2017.

[21] L. H. He, J. G. Wang, and J. Q. Xiao, "Pre-splitting blasting vibration reduction effect research on weak rock mass," International Journal of Rock Mechanics \& Mining Sciences, vol. 6, pp. 338-343, 2013.

[22] P. K. Singh, M. P. Roy, and R. K. Paswan, "Controlled blasting for long term stability of pit-walls," International Journal of Rock Mechanics and Mining Sciences, vol. 70, pp. 388-399, 2014.

[23] F. Wang, S. Tu, Y. Yuan, Y. Feng, F. Chen, and H. Tu, "Deephole pre-split blasting mechanism and its application for controlled roof caving in shallow depth seams," International Journal of Rock Mechanics and Mining Sciences, vol. 64, pp. 112-121, 2013.

[24] B. Huang, Q. Cheng, X. Zhao, and C. Kang, "Hydraulic fracturing of hard top coal and roof for controlling gas during the initial mining stages in longwall top coal caving: a case study," Journal of Geophysics and Engineering, vol. 15, no. 6, pp. 2492-2506, 2018.

[25] D. Zhao, Z. C. Feng, and Y. S. Zhao, Effects and Influences of Water Injection on Coalbed Exploitation in Mining Engineering, pp. 731-735, Press-Taylor \& Francis Group, Boca Raton, FL, USA, 2018.

[26] N. Zhang, C. Liu, and B. Chen, "A case study of presplitting blasting parameters of hard and massive roof based on the interaction between support and overlying strata," Energies, vol. 11, no. 6, p. 1363, 2018.

[27] Z. T. Zheng, Y. Xu, J. H. Dong, Q. Zong, and L. P. Wang, "Hard rock deep hole cutting blasting technology in vertical shaft freezing bedrock section construction," Journal of Vibroengineering, vol. 17, no. 3, pp. 1105-1119, 2015. 
[28] Z. Zheng, Y. Xu, D. Li, and J. Dong, "Numerical analysis and experimental study of hard roofs in fully mechanized mining faces under sleeve fracturing," Minerals, vol. 5, no. 4, pp. 758-777, 2015.

[29] Z. M. Ma, J. Wang, M. C. He, Y. B. Gao, J. Z. Hu, and J. Wang, "Key technologies and application test of an innovative noncoal pillar mining approach: a case study," Energies, vol. 11, no. 10, Article ID 2853, 2018.

[30] Q. W. Li, L. Qiao, G. Dasgupta, S. W. Ma, L. P. Wang, and J. H. Dong, "Blasting vibration safety criterion analysis with equivalent elastic boundary: based on accurate loading model," Shock and Vibration, vol. 2015, Article ID 604683, 2015.

[31] P. Wang, L. S. Jiang, J. Q. Jiang, P. Q. Zheng, and W. Li, "Strata behaviors and rock-burst-inducing mechanism under the coupling effect of a hard thick stratum and a normal fault," International Journal of Geomechanics, vol. 18, no. 2, Article ID 04017135, 2018.

[32] P. Wang, L. S. Jiang, P. Q. Zheng, G. P. Qin, and C. Zhang, "Inducing mode analysis of rock burst in fault-affected zone with a hard-thick stratum occurrence," Environmental Earth Sciences, vol. 78, p. 467, 2019.

[33] F. Meng, H. Zhou, Z. Wang et al., "Experimental study on the prediction of rockburst hazards induced by dynamic structural plane shearing in deeply buried hard rock tunnels," International Journal of Rock Mechanics and Mining Sciences, vol. 86, pp. 210-223, 2016.

[34] L. S. Jiang, P. Wang, P. Q. Zheng, H. J. Luan, and C. Zhang, "Influence of different advancing directions on mining effect caused by a fault," Advances in Civil Engineering, vol. 2019, Article ID 7306850, 10 pages, 2019.

[35] C. L. Han, Stress optimization and structure stability control for the surrounding rock of gob-side entry retaining, Ph.D. thesis, China University of Mining and Technology, Beijing, China, 2013.

[36] X. G. Ma, M. C. He, Z. Li, Y. X. Liu, G. Y. Yu, and H. R. Du, "Study on key parameters of roof cutting blasting design for self-formed roadway with composite roof without coal pillar," Journal of China University of Mining \& Technology, vol. 48, no. 02, pp. 236-277, 2019.

[37] J. Q. Tang, W. J. Song, L. B. Song, and Z. B. Guo, “Cutting seam design and study of gob-side entry retaining by roof cutting and pressure relief," Safety in Coal Mines, vol. 47, no. 09 , pp. 53-59, 2016.

[38] X. M. Sun, X. Liu, G. F. Liang, D. Wang, and Y. L. Jiang, "Key parameters of gob-side entry retaining formed by Roof cut and pressure releasing in thin coal seams," Chinese Journal of Rock Mechanics and Engineering, vol. 33, no. 07, pp. 14491456, 2014. 


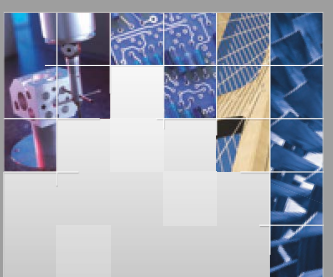

\section{Enfincering}
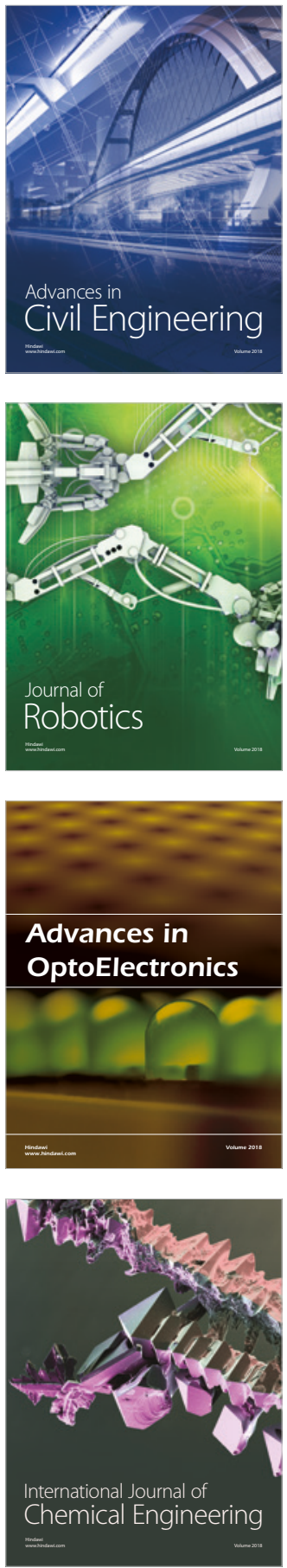

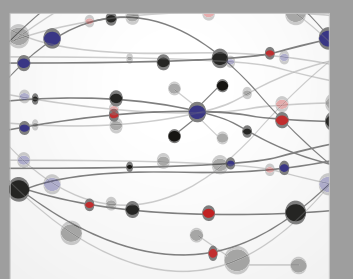

\section{Rotating \\ Machinery}

The Scientific World Journal

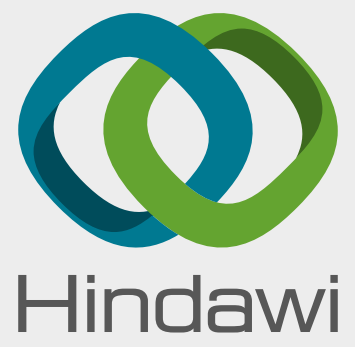

Submit your manuscripts at

www.hindawi.com
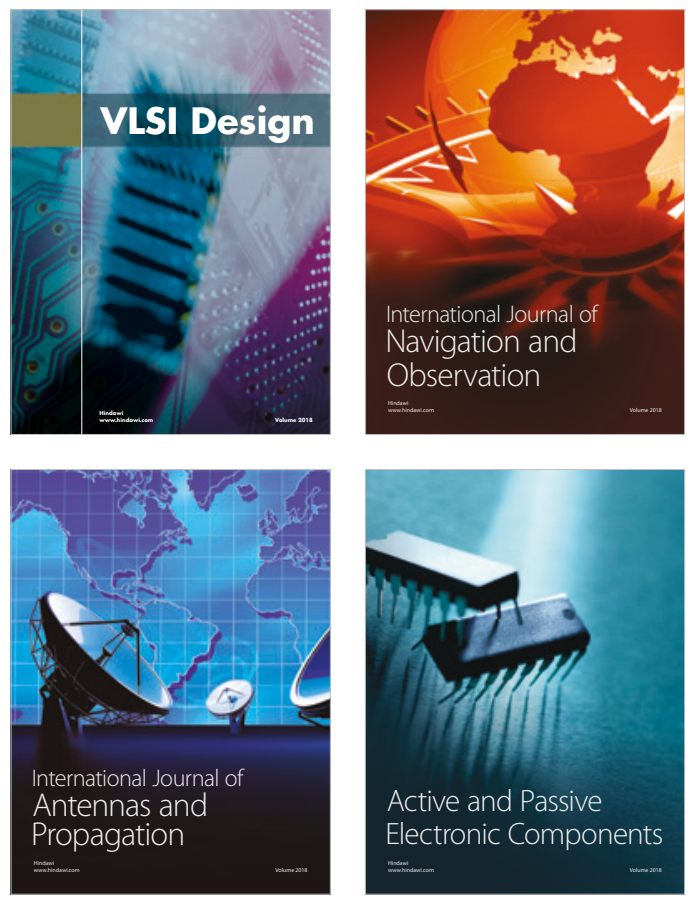
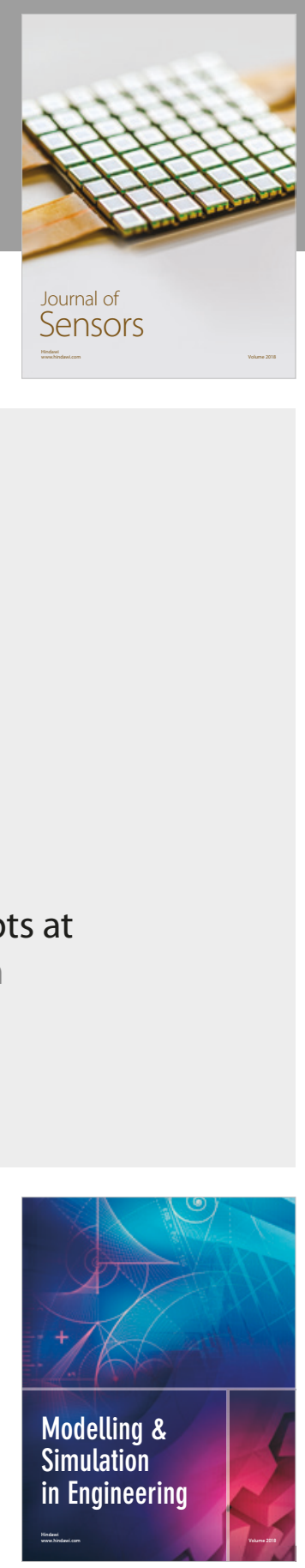

\section{Advances \\ Multimedia}
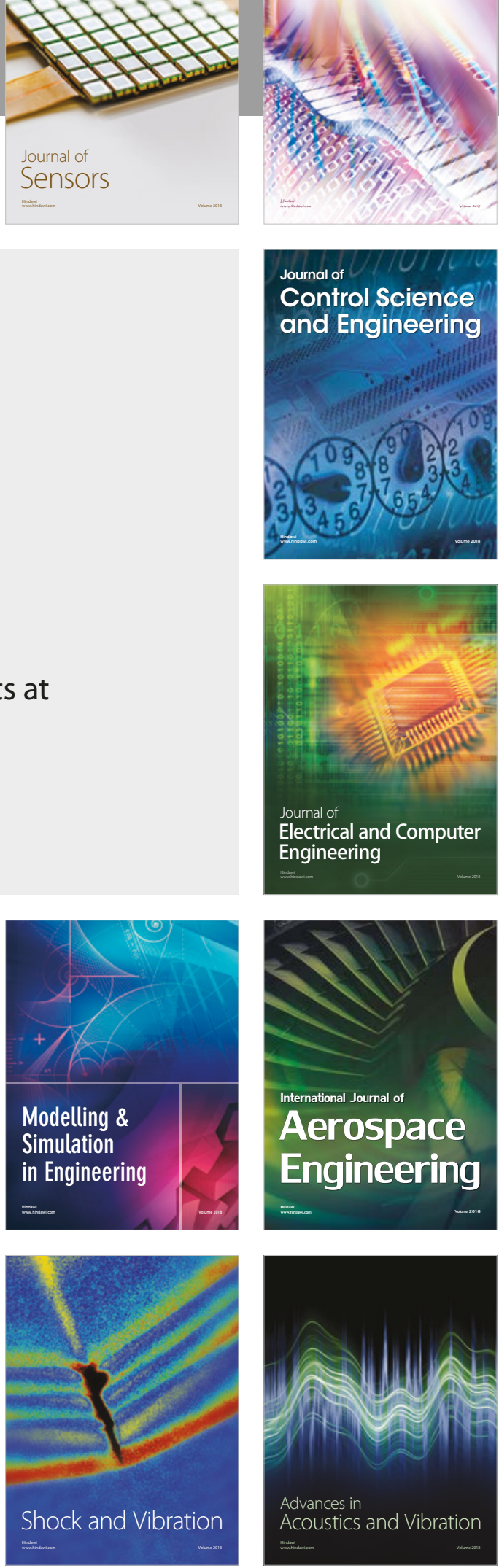